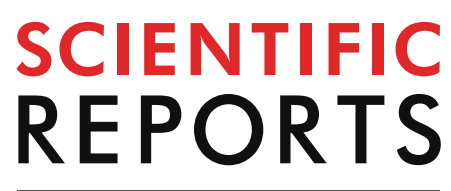

natureresearch

Check for updates

\title{
Increased
}

\section{both PD-L1 and PD-L2 expressions on monocytes of patients with hepatocellular carcinoma was associated with a poor prognosis}

\author{
Hidetaka Yasuoka, Akira Asai ${ }^{\bowtie}$, Hideko Ohama, Yusuke Tsuchimoto, Shinya Fukunishi \&
} Kazuhide Higuchi

Anti-programmed cell death-1 (PD-1) antibodies has been approved to treat HCC. Some PD-1 ligands (PD-L1 and PD-L2) negative tumors respond to treatment of anti-PD-1 antibodies, and this fact may be caused by the expression of PD-1 ligands on non-tumor cells. PD-L1 was recently found to be expressed on $\mathrm{CD} 14^{+}$cells from cancer patients. We investigate PD-1 ligands expression on CD14 ${ }^{+}$ cells of patients with $\mathrm{HCC}$ and the role of $\mathrm{CD} 14^{+}$cells in an antitumor response. In this study, 87 patients diagnosed with HCC were enrolled. CD14 ${ }^{+}$cells from patients with HCC expressed PD-L1 (4.5-95.5\%) and PD-L2 (0.2-95.0\%). According to cut-off values, we classified patients as those either with PD-L1 $1^{+}$PD-L2 ${ }^{+} \mathrm{CD} 14^{+}$cells or other types of $\mathrm{CD} 14^{+}$cells. The overall survival of patients with PD$\mathrm{L1}^{+} \mathrm{PD}-\mathrm{L2}{ }^{+} \mathrm{CD} 14^{+}$cells was shorter than that of patients with other types of $\mathrm{CD} 14^{+}$cells $(p=0.0023)$. PD-L1 ${ }^{+}$PD-L2 ${ }^{+}$CD14 ${ }^{+}$cells produced IL-10 and CCL1, and showed little tumoricidal activity against HepG2 cells. The tumoricidal activity of $C D 8^{+}$cells from patients with PD-L1+PD-L2+CD14 ${ }^{+}$cells were suppressed by co-cultivation with $\mathrm{CD} 14^{+}$cells from the syngeneic patient. Furthermore, anti-PD-1 antibody restored their tumoricidal activity of $\mathrm{CD}^{+}$cells. In conclusion, some patients with $\mathrm{HCC}$ have PD-L1+PD-L2 ${ }^{+} \mathrm{CD} 14^{+}$cells that suppress their antitumor response. These inhibitory functions of CD14 ${ }^{+}$ cells may be associated with a poor prognosis in these patients.

Hepatocellular carcinoma (HCC) is the sixth most common cancer and the fourth most common cause of cancer-related death worldwide. Most cases of HCC occur in patients with liver diseases caused by hepatitis B, hepatitis $\mathrm{C}$, alcoholic hepatitis or non-alcoholic steatohepatitis (NASH) ${ }^{1}$. Although various treatments for HCC exist, including surgery, radiofrequency ablation, microwave coagulation therapy, percutaneous ethanol injection therapy, transcatheter arterial chemoembolization, and molecular-targeted drugs, the prognosis of patients with this disease remains poor ${ }^{2-4}$. In spite of patients with HCC receiving such therapies, multifocal HCC often arises synchronously, and metastasizes as new tumors or as intrahepatic metastases of the primary cancer, leading to high mortality rates ${ }^{5-7}$. Therefore, a new treatment for HCC is urgently needed.

Cancer cells are transformed from normal cells in response to carcinogens and other genotoxic insults in addition to the failure of intrinsic tumor suppressor mechanisms (e.g., p53, ataxia telangiectasia mutated) ${ }^{8}$. An immune surveillance system exists that monitors and eliminates cancer cells. However, cancer cells escape surveillance by a process known as cancer immunoediting.

Recently, a new immunosuppressive pathway, the programmed cell death 1 (PD-1) pathway that is involved in the immune evasion of cancer, has been discovered. The PD-1 pathway is activated by programmed cell death 1 ligand 1 (PD-L1) or programmed cell death 1 ligand 2 (PD-L2) binding to PD-1 expressed on T cells. Activation 


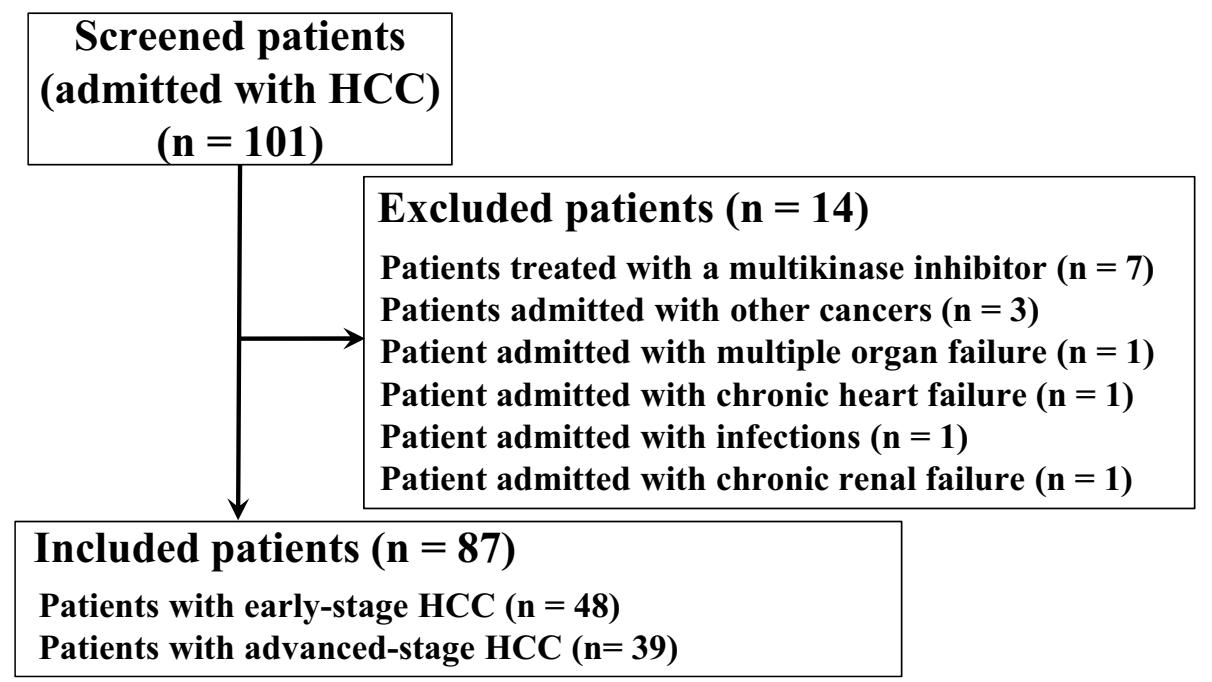

Figure 1. Flow chart of eligible and included patients in this study.

of the PD-1 pathway suppresses the differentiation of naïve $\mathrm{CD} 8^{+}$cells into cytotoxic T lymphocytes (CTLs) and also leads to the exhaustion of CTLs to finally suppress the antitumor immune response of CTLs ${ }^{9-11}$. The PD-1 pathway suppresses antitumor immunity by the aforementioned mechanisms. And PD-L2 expression on tumor cells may promote tumor metastasis and predict poor prognosis in solid cancer patients in $\mathrm{HCC}^{12}$. In recent years, reports on the expressions of PD-L1 and PD-L2 in multiple types of host cells in the tumor environment including dendritic cells, macrophages, fibroblasts and $\mathrm{T}$ cells have been increased ${ }^{13}$. There are some reports according to the correlation between the expression PD-L1 or PD-L2 in HCC and the prognosis ${ }^{14-16}$. However, relationship between monocytes which expressed both PD-L1 and PD-L2 and the prognosis of the diseases is unclear.

Nivolumab, an anti-PD-1 antibody, was first approved for the treatment of HCC in the U.S.A. in November 2017. The anti-PD-1 antibody augments the antitumor response of CD8 ${ }^{+}$cells by blocking the PD-1 pathway. Clinical trials suggest that blockade of the PD-1 pathway induces sustained tumor regression in various tumor types. More specifically, responses to anti-PD-1 antibody may correlate with the expression of PD-1 ligands by cancer cells.

However, some PD-L1-positive tumors do not respond to anti-PD-1 antibody, while a proportion of PD-L1-negative tumors react with this antibody ${ }^{17,18}$. Discrepancies associated with a clinical response to antiPD-1 antibody and PD-L1 expression on the tumor are not fully understood, although several mechanisms have been suggested ${ }^{19,20}$.

Cancer cells that express PD-L1 suppress the antitumor response of $\mathrm{CD}^{+}$cells by activating the PD-1 pathway ${ }^{11,21,22}$. In recent years, monocytes $/ \mathrm{M} \varphi$ have been found to also express PD-L1 ${ }^{23,24}$. PD-L1 is also expressed on $\mathrm{CD} 14^{+}$cells from patients with diverse cancers. As with $\mathrm{CD} 8^{+}$cells, $\mathrm{CD} 14^{+}$cells also kill cancer cells.

In this study, we investigated the relationship between the prognosis of HCC and the expression of PD-L1 and PD-L2 on CD14 $4^{+}$cells. We also examined the inhibitory function of monocytes/M $\varphi$ against the antitumor response of $\mathrm{CD}^{+}$cells by the $\mathrm{PD}-1$ pathway, and the restorative effect of an anti-PD-1 antibody on the antitumor response of $\mathrm{CD}^{+}$cells.

\section{Results}

Relationship between PD-L1 and PD-L2 expression on CD14 ${ }^{+}$cells and patient prognoses. Total 101 patients were enrolled in this study and 87 patients were eligible (Fig. 1). The mean age of included patients ( 87 cases) was 74.1 years. Of these patients, 68 were male and 19 were female. The etiology of HCC was hepatitis B-related liver disease for 17 patients, and hepatitis C-related liver disease for 39 patients, while the HCC of 31 patients had other etiologies. Forty-eight patients presented with early-stage HCC, while the remaining 39 patients presented with advanced-stage HCC. Seventy-five, eleven and one patient had ChildPugh class A, B, and C cirrhosis, respectively. Mean hematological values for these patients were $143.9(\mathrm{ng} / \mathrm{ml})$ for alpha fetoprotein (AFP), $300.3(\mathrm{mAU} / \mathrm{ml})$ for des-gamma-carboxyl prothrombin (DCP), $4.75\left(\times 10^{6} \mathrm{cells} / \mathrm{ml}\right)$ for the white blood cell (WBC) count, $1.28\left(\times 10^{6}\right.$ cells $\left./ \mathrm{ml}\right)$ for the lymphocyte count, $3.21\left(\times 10^{4}\right.$ cells $\left./ \mathrm{ml}\right)$ for the $\mathrm{CD} 14^{+}$cell count, and $4.93\left(\times 10^{3}\right.$ cells $\left./ \mathrm{ml}\right)$ for the $\mathrm{CD} 8^{+}$cell count (Table 1$)$. CD $14^{+}$cells from these patients expressed PD-L1 (range 4.5-95.5\%) and PD-L2 (range 0.2-95.0\%; Fig. 2a,b).

We set cut-off values as the mean value of PD-L1 (50.8\%) and PD-L2 (45.8\%) expression. With reference to the cut-off values, we classified patients as having either PD-L $1^{+} \mathrm{PD}-\mathrm{L} 2^{+} \mathrm{CD} 14^{+}$cells or other types of CD $14^{+}$ cells (PD-L1 ${ }^{+} \mathrm{PD}-\mathrm{L} 2^{-} \mathrm{CD} 14^{+}$cells, $\mathrm{PD}-\mathrm{L} 1^{-} \mathrm{PD}-\mathrm{L} 2^{+} \mathrm{CD} 14^{+}$cells or PD-L1 ${ }^{-} \mathrm{PD}-\mathrm{L} 2^{-} \mathrm{CD} 14^{+}$cells). HCC stage and TNM stage of Patients with $\mathrm{PD}-\mathrm{L} 1^{+} \mathrm{PD}-\mathrm{L} 2^{+} \mathrm{CD} 14^{+}$cells was different those of patients with other types of $\mathrm{CD} 14^{+}$cells. In this study, there was no difference in white blood cell counts and neutrophils between patients with $\mathrm{PD}-\mathrm{L} 1^{+} \mathrm{PD}-\mathrm{L} 2^{+} \mathrm{CD} 14^{+}$cells and other types of $\mathrm{CD} 14^{+}$cells (Table 3 ). We found that the overall survival of patients with $\mathrm{PD}-\mathrm{L} 1^{+} \mathrm{PD}-\mathrm{L} 2^{+} \mathrm{CD} 14^{+}$cells was significantly shorter than that of patients with other types of CD $14^{+}$cells $(p=0.0023$; Fig. $2 c)$. Cancer specific survivals (CSS) have similar results to the overall survival. CSS 


\begin{tabular}{|c|c|}
\hline All case & 87 \\
\hline Age (year, range) & $74.1(46-88)$ \\
\hline \multicolumn{2}{|l|}{ Gender (\%) } \\
\hline Male & $68(78.2)$ \\
\hline Female & $19(21.8)$ \\
\hline \multicolumn{2}{|l|}{ Etiology (\%) } \\
\hline $\mathrm{HBV}$ & $17(19.5)$ \\
\hline $\mathrm{HCV}$ & $39(44.8)$ \\
\hline Others & $31(35.6)$ \\
\hline \multicolumn{2}{|l|}{ HCC stage (\%) } \\
\hline Early & $48(55.2)$ \\
\hline Advanced & $39(44.8)$ \\
\hline \multicolumn{2}{|l|}{ TNM stage } \\
\hline I/II/III/IV & $28 / 25 / 22 / 12$ \\
\hline \multicolumn{2}{|l|}{ Child-Pugh class } \\
\hline $\mathrm{A} / \mathrm{B} / \mathrm{C}$ & $75 / 11 / 1$ \\
\hline AFP (ng/ml, range) & $143.9(1.0-4,266.0)$ \\
\hline $\mathrm{DCP}(\mathrm{mAU} / \mathrm{ml}$, range $)$ & $300.3(9.5-9,060.2)$ \\
\hline $\mathrm{CRP}(\mathrm{mg} / \mathrm{dl}$, mean $\pm \mathrm{SD})$ & $0.41 \pm 0.67$ \\
\hline $\mathrm{WBC}\left(\times 10^{6} / \mathrm{ml}\right.$, mean $\left.\pm \mathrm{SD}\right)$ & $4.75 \pm 1.32$ \\
\hline Neut $\left(\times 10^{6} / \mathrm{ml}\right.$, mean $\left.\pm \mathrm{SD}\right)$ & $2.95 \pm 0.96$ \\
\hline Lymphocytes $\left(\times 10^{6} / \mathrm{ml}\right.$, mean \pm SD $)$ & $1.28 \pm 0.60$ \\
\hline $\mathrm{CD} 14^{+}$cells $\left(\times 10^{4} / \mathrm{ml}\right.$, mean $\left.\pm \mathrm{SD}\right)$ & $3.21 \pm 1.18$ \\
\hline $\mathrm{CD}^{+}$cells $\left(\times 10^{4} / \mathrm{ml}\right.$, mean $\left.\pm \mathrm{SD}\right)$ & $4.93 \pm 2.79$ \\
\hline \multicolumn{2}{|l|}{ Pretreatment } \\
\hline Surgery/RFA/TACE & $22 / 27 / 15$ \\
\hline
\end{tabular}

Table 1. Clinical background of all patients. $H B V$ hepatitis B virus, $H C V$ hepatitis $C$ virus, $H C C$ hepatocellular carcinoma, $P D-L 1$ programmed cell death 1 ligand 1, $P D-L 2$ programmed cell death 1 ligand 2, $A F P$ alpha fetoprotein, $D C P$ des-gamma-carboxyl prothrombin, Neut neutrophil, CRP C-reactive protein, $W B C$ white blood cells, $S D$ standard deviation, RFA radiofrequency ablation, TACE transcatheter arterial chemoembolization.

of patients with $\mathrm{PD}-\mathrm{L} 1^{+} \mathrm{PD}-\mathrm{L} 2^{+} \mathrm{CD} 14^{+}$cells was significantly shorter than that of patients with other types of $\mathrm{CD} 14^{+}$cells $(p=0.0055)$ (Fig. $\left.2 \mathrm{~d}\right)$. Furthermore, early-stage HCC patients with $\mathrm{PD}-\mathrm{L} 1^{+} \mathrm{PD}-\mathrm{L} 2^{+} \mathrm{CD} 14^{+}$cells and similar patients with other types of $\mathrm{CD}_{1} 4^{+}$cells did not show a significant difference in overall survival (Fig. 3a). However, overall survival of advanced-stage HCC patients with PD-L1 ${ }^{+} \mathrm{PD}-\mathrm{L} 2^{+} \mathrm{CD} 14^{+}$cells was significantly shorter than similar patients with other types of CD14 ${ }^{+}$cells $(p=0.0393$; Fig. $3 \mathrm{~b})$. There was no difference in the prognosis between patients with $\mathrm{PD}-\mathrm{L} 1^{+} \mathrm{CD} 14^{+}$cells and with $\mathrm{PD}-\mathrm{L} 1^{-} \mathrm{CD} 14^{+}$cells. However, compared with the prognosis of patients with PD-L1 $1^{+} \mathrm{PDL}-2^{-} \mathrm{CD} 14^{+}$cells and that with $\mathrm{PD}-\mathrm{L} 1^{+} \mathrm{PDL}-2^{+} \mathrm{CD} 14^{+}$cells, the prognosis of patients with $\mathrm{PD}-\mathrm{L} 1^{+} \mathrm{PD}-\mathrm{L} 2^{+} \mathrm{CD} 14^{+}$cells was shorter than that of patients with $\mathrm{PD}-\mathrm{L} 1^{+} \mathrm{PD}-\mathrm{L} 2^{-} \mathrm{CD} 14^{+}$cells (SI Fig. S1). The mean age of twelve patients with HCC who died was 70.8 years. Deaths in such patients were almost cancer-related (Table 2). Of these patients, nine were male and three were female. The etiology of HCC in five cases was hepatitis B-related liver disease, for two cases it was hepatitis C-related liver disease, and for four case it was NASH-related liver disease. The mean expression of PD-L1 and PD-L2 on CD14 $4^{+}$cells from patients with HCC who died was $58.1 \%$ and $62.3 \%$, respectively; these patients almost all had PD-L1 $1^{+} \mathrm{PD}-\mathrm{L} 2^{+} \mathrm{CD} 14^{+}$ cells. Thus, $\mathrm{CD} 14^{+}$cells from patients with HCC expressed both PD-L1 and PD-L2. Those patients expressing high levels of PD-L1 and PD-L2 on their CD14 ${ }^{+}$cells were found to show shorter overall survival, with most deaths being cancer-related.

Clinical characteristics of patients with PD-L1+PD-L2+CD14 ${ }^{+}$cells or other types of CD14 ${ }^{+}$ cells. Table 3 summarizes the clinical characteristics of patients with $\mathrm{PD}-\mathrm{L} 1^{+} \mathrm{PD}-\mathrm{L} 2^{+} \mathrm{CD} 14^{+}$cells and patients with other types of $\mathrm{CD}_{1} 4^{+}$cells. The two groups of patients did not show any significant differences in age, gender, etiology, Child-Pugh class, pretreatment and hematological values (AFP, DCP, WBC count, lymphocyte count, and $\mathrm{CD}_{14}^{+}$and $\mathrm{CD} 8^{+}$cell counts). However, HCC stages and TNM stages in patients with PD-L1 ${ }^{+} \mathrm{PD}-$ $\mathrm{L} 2{ }^{+} \mathrm{CD} 14^{+}$cells were almost all advanced, while those in patients with other types of $\mathrm{CD} 14^{+}$cells were mostly early stage. And, there was a significant difference in the value of CRP only. However, the value of CRP of patients with other types of CD14 ${ }^{+}$cells was slightly high, but the mean value of 2 or less. Interestingly, even if patients with advanced-stage cancer, patients with $\mathrm{PD}-\mathrm{L} 1^{+} \mathrm{PD}-\mathrm{L} 2^{+} \mathrm{CD} 14^{+}$cells also have poorer prognosis than similar patients with other types of CD $14^{+}$cells (Fig. 3b). 
(a)
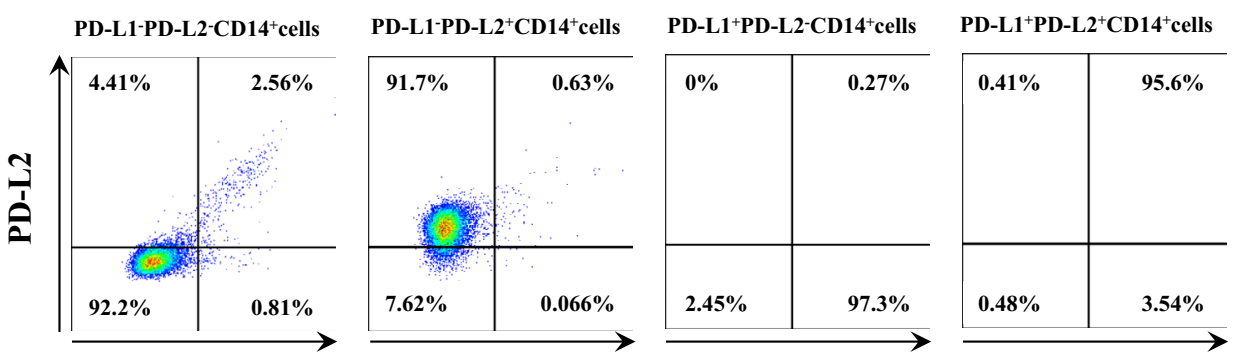

PD-L1

(b)

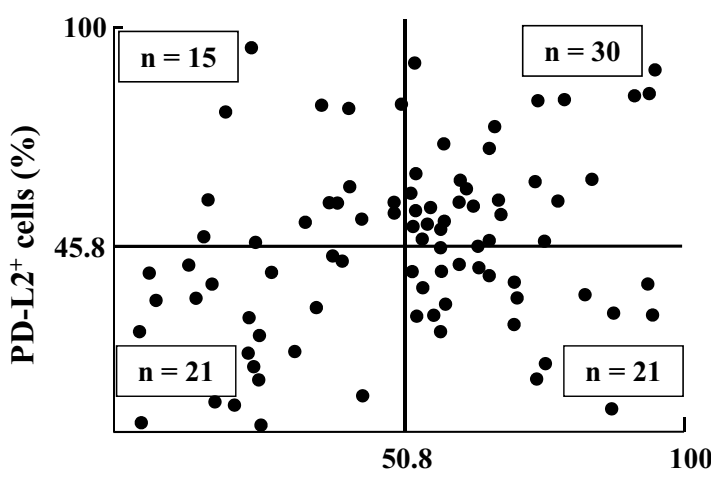

PD-L1 ${ }^{+}$cells $(\%)$ (c) Patients with HCC

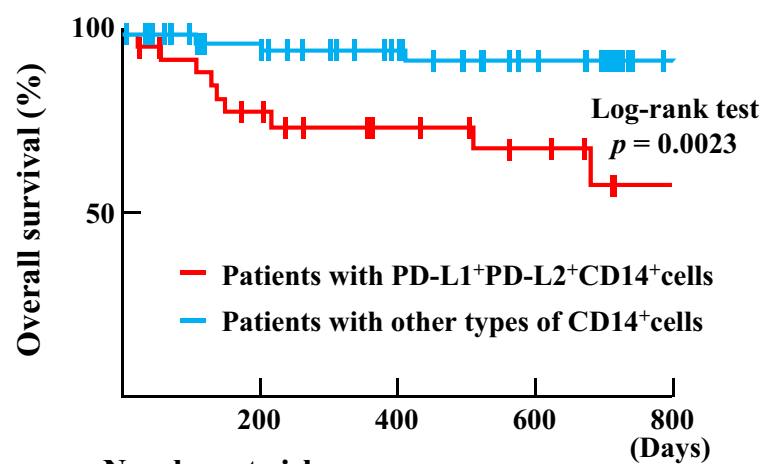

PD-L1 ${ }^{+}$PD-L2 $2^{+}$Number at risk

\begin{tabular}{lccccc|} 
CD14 & + cells \\
\cline { 2 - 6 } Other types of & 30 & 21 & 14 & 10 & 4 \\
CD14 & 57 & 43 & 33 & 22 & 9 \\
\cline { 2 - 7 } & 0 & 200 & 400 & 600 & $\begin{array}{c}\text { 800 } \\
\text { (Days) }\end{array}$
\end{tabular}

(d) Patients with HCC

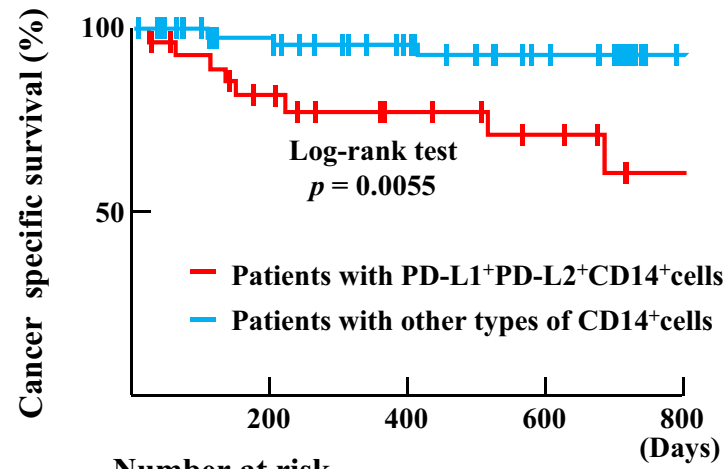

\begin{tabular}{|c|c|c|c|c|c|}
\hline \multirow{2}{*}{$\begin{array}{l}\text { PD-L1 }^{+}{ }^{+} \text {PD-L2 } \\
\text { CD14 }^{+} \text {cells }\end{array}$} & \multicolumn{5}{|c|}{ Number at risk } \\
\hline & 30 & 21 & 14 & 10 & 4 \\
\hline oes of & 57 & 43 & 33 & 22 & 9 \\
\hline${\mathrm{CD} 14^{+} \text {cells }}$ & 0 & 200 & 400 & 600 & $\begin{array}{c}800 \\
\text { (Days) }\end{array}$ \\
\hline
\end{tabular}

Figure 2. Relationship between PD-L1 and PD-L2 expression on $\mathrm{CD} 14^{+}$cells and patient prognoses. (a) $\mathrm{CD} 14^{+}$cells isolated from patients with hepatocellular carcinoma (HCC) were classified into four subgroups (PD-L1 ${ }^{+} \mathrm{PD}-\mathrm{L} 2^{+} \mathrm{CD} 14^{+}$cells, PD-L1 ${ }^{+} \mathrm{PD}-\mathrm{L2}^{-} \mathrm{CD} 14^{+}$cells, $\mathrm{PD}-\mathrm{L} 1^{-} \mathrm{PD}-\mathrm{L} 2^{+} \mathrm{CD} 14^{+}$cells and PD-L1-PD-L2 CD14 ${ }^{+}$cells). (b) PD-L1 and PD-L2 expression of CD14 $4^{+}$cells from patients with HCC $(\mathrm{n}=87)$. The average value of $\mathrm{PD}-\mathrm{L} 1$ expression on $\mathrm{CD} 14^{+}$cells was $50.8 \%$, and the average value of $\mathrm{PD}-\mathrm{L} 2$ expression on $\mathrm{CD} 14^{+}$ cells was $45.8 \%$. (c) Kaplan-Meier curves for overall survival (OS) in patients with PD-L1 ${ }^{+} \mathrm{PD}-\mathrm{L} 2^{+} \mathrm{CD} 14^{+}$cells $(n=30$; red line $)$ and patients with other types of $C D 14^{+}$cells $(n=57$; blue line) were drawn. (d) Kaplan-Meier curves for cancer specific survival in patients with PD-L1 ${ }^{+} \mathrm{PD}-\mathrm{L} 2^{+} \mathrm{CD} 14^{+}$cells $(\mathrm{n}=30$; red line) and patients with other types of $\mathrm{CD} 14^{+}$cells $(\mathrm{n}=57$; blue line). 
(a) Early stage-HCC patients

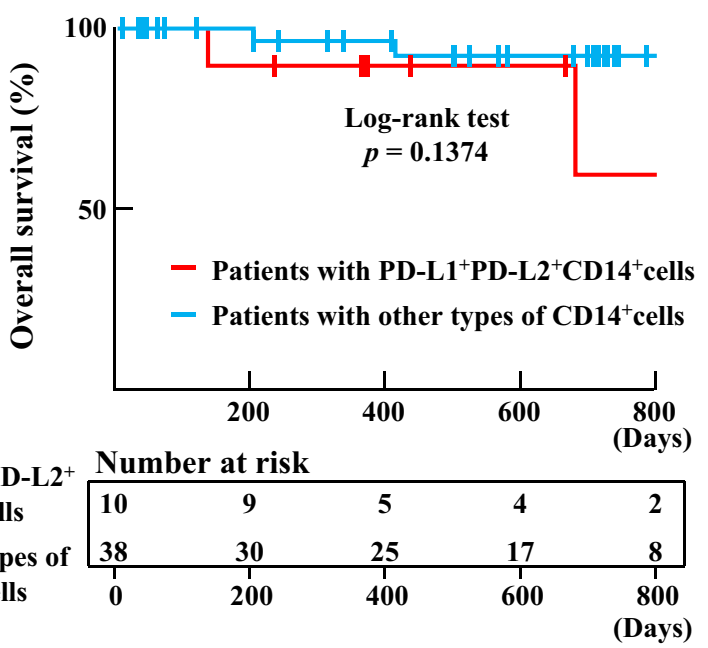

(b) Advanced stage-HCC patients

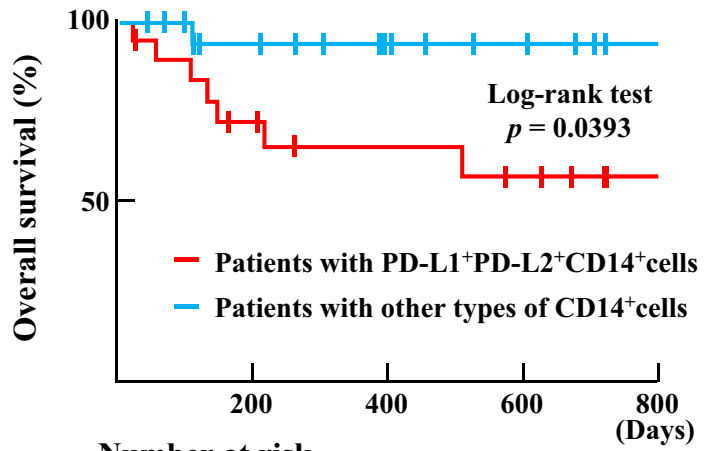

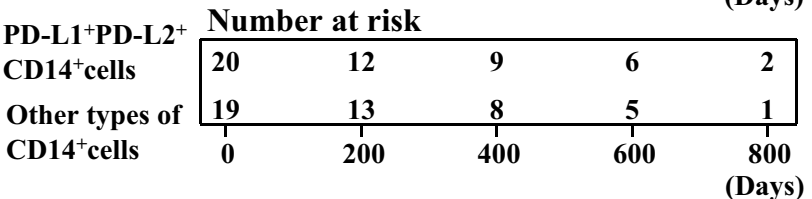

Figure 3. Overall survivals of HCC patients. (a) Kaplan-Meier curves for OS in early-stage HCC patients with $\mathrm{PD}-\mathrm{L} 1^{+} \mathrm{PD}-\mathrm{L} 2^{+} \mathrm{CD} 14^{+}$cells $\left(\mathrm{n}=10\right.$; red line) and early-stage HCC patients with other types of CD14 ${ }^{+}$ cells $(n=38$; blue line) were drawn. (b) Kaplan-Meier curves for OS in advanced-stage HCC patients with $\mathrm{PD}-\mathrm{L} 1^{+} \mathrm{PD}-\mathrm{L} 2^{+} \mathrm{CD} 14^{+}$cells $\left(\mathrm{n}=20\right.$; red line) and advanced-stage HCC patients with other types of CD $14^{+}$cells $(\mathrm{n}=19$; blue line) were drawn.

\begin{tabular}{|l|l|l|l|l|l|l|l|}
\hline No & Age & Gender & Etiology & PD-L1 (\%) & PD-L2 (\%) & OS (days) & Cause of death \\
\hline 1 & 65 & Female & HCV & 93.9 & 84.4 & 104 & Cancer \\
\hline 2 & 68 & Female & HCV & 41 & 80.9 & 104 & Cancer \\
\hline 3 & 77 & Male & NASH & 62.2 & 60.2 & 215 & Cancer \\
\hline 4 & 75 & Male & HBV & 61.3 & 61.7 & 19 & Cancer \\
\hline 5 & 65 & Female & HBV & 53.2 & 64.1 & 52 & Cancer \\
\hline 6 & 72 & Male & HBV & 38.8 & 56.7 & 202 & Cancer \\
\hline 7 & 69 & Male & HBV & 58.0 & 52.0 & 133 & Varix rupture \\
\hline 8 & 71 & Male & HBV & 67.6 & 57.5 & 510 & Cancer \\
\hline 9 & 77 & Male & NASH & 38.7 & 43.5 & 411 & Cancer \\
\hline 10 & 66 & Male & NASH & 67.2 & 75.7 & 130 & Cancer \\
\hline 11 & 67 & Male & ALD & 52.2 & 54.6 & 680 & Cancer \\
\hline 12 & 78 & Male & NASH & 62.9 & 56.8 & 144 & Cancer \\
\hline
\end{tabular}

Table 2. Clinical background of deceased patients. $H B V$ hepatitis B virus, $H C V$ hepatitis $\mathrm{C}$ virus, NASH nonalcoholic steatohepatitis, $A L D$ alcohol liver disease.

CD14 ${ }^{+}$cell properties of PD-L1 ${ }^{+} \mathrm{PD}-\mathrm{L} 22^{+} \mathrm{CD} 14^{+}$cells and other types of $\mathrm{CD} 14^{+}$cells. The mean IL-12 level in the culture fluid of other types of $\mathrm{CD} 14^{+}$cells was as same as that of PD-L1 ${ }^{+} \mathrm{PD}-\mathrm{L} 2^{+} \mathrm{CD} 14^{+}$cells (Fig. 4a). In contrast, the mean IL-10 level in the culture fluid of other types of CD14 $4^{+}$cells was lower than that of PD-L1+PD-L2 ${ }^{+} \mathrm{CD} 14^{+}$cells (Fig. 4b). Both groups of CD14 ${ }^{+}$cells did not produce CCL17 and CXCL13, while only PD-L1 ${ }^{+} \mathrm{PD}-\mathrm{L} 2^{+} \mathrm{CD} 14^{+}$cells produced CCL1 (Fig. 4c-e). In SI Fig. S2, the cytokine secretion and tumoricidal activity of each group of $\mathrm{CD} 14^{+}$cells (PD-L1 ${ }^{+} \mathrm{PD}-\mathrm{L} 2^{+} \mathrm{CD} 14^{+}$cells, $\mathrm{PD}-\mathrm{L} 1^{+} \mathrm{PD}-\mathrm{L} 2^{-} \mathrm{CD} 14^{+}$cells, PD-L1 ${ }^{-} \mathrm{PD}-\mathrm{L} 2^{+} \mathrm{CD} 14^{+}$cells and PD-L1 ${ }^{-} \mathrm{PD}-\mathrm{L} 2^{-} \mathrm{CD} 14^{+}$cells) were described. Although, other types of $\mathrm{CD} 14^{+}$ cells showed tumoricidal activities against HepG2 cells $(48.0 \pm 15.4 \%), \mathrm{PD}-\mathrm{L} 1{ }^{+} \mathrm{PD}-\mathrm{L} 2^{+} \mathrm{CD} 14^{+}$cells showed very little tumoricidal activities against HepG2 cells (10.8 $\pm 9.8 \%$; Fig. 4f). Similarly, the tumoricidal activity of PD$\mathrm{L} 1^{+} \mathrm{PD}-\mathrm{L} 2^{+} \mathrm{CD} 14^{+}$cells against Huh7 cells was lower than that of other types of $\mathrm{CD} 14^{+}$cells (SI Fig. S3). These results indicated that $\mathrm{PD}-\mathrm{L} 1^{+} \mathrm{PD}-\mathrm{L} 2^{+} \mathrm{CD} 14^{+}$cells expressed $\mathrm{M} 2 \mathrm{~b}$ phenotypic properties and these cells did not have the tumoricidal activity against hepatocellular carcinoma.

Anti-PD-1 antibody restored tumoricidal activities of $\mathrm{CD8}^{+}$cells suppressed by PD-L1+PD$\mathrm{L} 2^{+} \mathrm{CD} 14^{+}$cells isolated from the same patient. $\mathrm{CD} 8^{+}$cells isolated from patients with $\mathrm{PD}-\mathrm{L} 1^{+} \mathrm{PD}-$ $\mathrm{L}^{+} \mathrm{CD} 14^{+}$cells showed tumoricidal activities against HepG2 cells $(59.0 \pm 25.0 \%)$. After $\mathrm{CD} 8^{+}$cells were co-cultured with $\mathrm{PD}-\mathrm{L} 1^{+} \mathrm{PD}-\mathrm{L} 2^{+} \mathrm{CD} 14^{+}$cells isolated from the syngeneic patient for $24 \mathrm{~h}$, their tumoricidal activities were strongly suppressed $(16.3 \pm 16.0 \%)$. However, $\mathrm{CD} 8^{+}$cells isolated from patients with other types of $\mathrm{CD} 14^{+}$ cells showed the same levels of tumoricidal activities against HepG2 cells, with or without co-cultivation with 


\begin{tabular}{|c|c|c|c|}
\hline & Patients with PD-L1 ${ }^{+} \mathrm{PD}-\mathrm{L2}^{+} \mathrm{CD}^{+} 4^{+}$cells & Patients with other types of $\mathrm{CD} 14^{+}$cells & $p$ value \\
\hline All cases & 30 & 57 & \\
\hline Age (year, range) & $75(63-87)$ & $73.7(46-88)$ & 0.7374 \\
\hline \multicolumn{3}{|l|}{ Gender (\%) } & 0.4289 \\
\hline Male & $22(73.3)$ & $46(80.7)$ & \\
\hline Female & $8(26.7)$ & $11(19.3)$ & \\
\hline \multicolumn{3}{|l|}{ Etiology (\%) } & 0.5397 \\
\hline HBV & $6(20.0)$ & $11(19.3)$ & \\
\hline $\mathrm{HCV}$ & $11(36.7)$ & $28(49.1)$ & \\
\hline Others & $13(43.3)$ & $18(31.6)$ & \\
\hline \multicolumn{3}{|l|}{ HCC stage (\%) } & 0.0036 \\
\hline Early & $10(33.3)$ & $38(66.7)$ & \\
\hline Advanced & $20(66.7)$ & $19(33.3)$ & \\
\hline \multicolumn{3}{|l|}{ TNM stage } & 0.0024 \\
\hline I/II/III/IV & $3 / 13 / 7 / 7$ & $25 / 12 / 15 / 5$ & \\
\hline \multicolumn{3}{|l|}{ Child-Pugh class } & 0.2896 \\
\hline $\mathrm{A} / \mathrm{B} / \mathrm{C}$ & $24 / 5 / 1$ & $51 / 6 / 0$ & \\
\hline AFP (ng/ml, range) & $207.6(1.5-2,969.0)$ & $113.2(1-4,266.0)$ & 0.1624 \\
\hline $\mathrm{DCP}(\mathrm{mAU} / \mathrm{ml}$, range $)$ & $169.9(15.4-865.7)$ & $359.7(9.5-9,060.2)$ & 0.4455 \\
\hline $\mathrm{CRP}(\mathrm{mg} / \mathrm{dl}$, mean $\pm \mathrm{SD})$ & $0.61 \pm 0.81$ & $0.31 \pm 0.56$ & 0.0055 \\
\hline $\mathrm{WBC}\left(\times 10^{6} / \mathrm{ml}\right.$, mean $\left.\pm \mathrm{SD}\right)$ & $4.52 \pm 1.49$ & $4.88 \pm 1.22$ & 0.2512 \\
\hline Neut $\left(\times 10^{6} / \mathrm{ml}\right.$, mean $\left.\pm \mathrm{SD}\right)$ & $2.87 \pm 0.95$ & $2.99 \pm 0.97$ & 0.7109 \\
\hline Lymphocytes $\left(\times 10^{6} / \mathrm{ml}\right.$, mean $\left.\pm \mathrm{SD}\right)$ & $1.19 \pm 0.63$ & $1.32 \pm 0.59$ & 0.3416 \\
\hline CD $14^{+}$cells $\left(\times 10^{4} / \mathrm{ml}\right.$, mean $\left.\pm \mathrm{SD}\right)$ & $3.09 \pm 1.05$ & $3.28 \pm 1.24$ & 0.5890 \\
\hline $\mathrm{CD}^{+}$cells $\left(\times 10^{4} / \mathrm{ml}\right.$, mean $\left.\pm \mathrm{SD}\right)$ & $4.08 \pm 1.59$ & $5.59 \pm 3.34$ & 0.3447 \\
\hline \multicolumn{3}{|l|}{ Pretreatment } & 0.3418 \\
\hline Surgery/RFA/TACE & $8 / 8 / 8$ & $14 / 19 / 7$ & \\
\hline
\end{tabular}

Table 3. Clinical characteristics of patients with $\mathrm{PD}-\mathrm{L} 1^{+} \mathrm{PD}-\mathrm{L} 2^{+} \mathrm{CD} 14^{+}$cells and those with other types of $\mathrm{CD}_{14}{ }^{+}$cells. AFP alpha fetoprotein, $D C P$ des-gamma-carboxyl prothrombin, Neut neutrophil, CRP C-reactive protein, $W B C$ white blood cells, $S D$ standard deviation, $R F A$ radiofrequency ablation, TACE transcatheter arterial chemoembolization.

other types of $\mathrm{CD} 14^{+}$cells isolated from the syngeneic patients (Fig. 5a). In SI Fig. S4a, the tumoricidal activity of $\mathrm{CD} 8^{+}$cells from each group of patients with other types of CD14 ${ }^{+}$cells (patients with $\mathrm{PD}-\mathrm{L} 1^{+} \mathrm{PD}-\mathrm{L} 2^{-} \mathrm{CD} 14^{+}$ cells, patients with PD-L1 ${ }^{-} \mathrm{PD}-\mathrm{L} 2^{+} \mathrm{CD} 14^{+}$cells or patients with PD-L1 ${ }^{-} \mathrm{PD}-\mathrm{L} 2^{-} \mathrm{CD} 14^{+}$cells) were described. These results suggested that $\mathrm{PD}-\mathrm{L} 1^{+} \mathrm{PD}-\mathrm{L} 2^{+} \mathrm{CD} 14^{+}$cells suppressed the tumoricidal activities of $\mathrm{CD} 8^{+}$cells against HepG2 cells isolated from the syngeneic patient.

Next, $\mathrm{CD}^{+}$cells isolated from patients with $\mathrm{PD}-\mathrm{L} 1^{+} \mathrm{PD}-\mathrm{L} 2^{+} \mathrm{CD} 14^{+}$cells were co-cultured with $\mathrm{PD}-\mathrm{L} 1^{+} \mathrm{PD}-\mathrm{L} 2^{+} \mathrm{CD} 14^{+}$cells from the syngeneic patients under the stimulation of anti-PD-1 antibody. Anti$\mathrm{PD}-1$ antibody restored the tumoricidal activities of $\mathrm{CD} 8^{+}$cells co-cultured with $\mathrm{PD}-\mathrm{L} 1^{+} \mathrm{PD}-\mathrm{L} 2^{+} \mathrm{CD} 14^{+}$cells $(53.3 \pm 33.7 \%)$ to the same levels as those of $\mathrm{CD}^{+}$cells that were cultured without PD-L1 ${ }^{+} \mathrm{PD}-\mathrm{L} 2^{+} \mathrm{CD} 14^{+}$cells (Fig. 5b). In supplemental Fig. 4b, tumoricidal activity of $\mathrm{CD}^{+}$cells from each group of patients with other types of $\mathrm{CD} 14^{+}$cells (patients with $\mathrm{PD}-\mathrm{L} 1^{+} \mathrm{PD}-\mathrm{L} 2^{-} \mathrm{CD} 14^{+}$cells, patients with $\mathrm{PD}-\mathrm{L} 1^{-} \mathrm{PD}-\mathrm{L} 2^{+} \mathrm{CD} 14^{+}$cells or patients with PD-L1-PD-L2 ${ }^{-} \mathrm{CD} 14^{+}$cells) did not change, whether these $\mathrm{CD} 8^{+}$cells were stimulated with anti-PD-1 antibody. Thus, $\mathrm{PD}-\mathrm{L} 1^{+} \mathrm{PD}-\mathrm{L} 2^{+} \mathrm{CD} 14^{+}$cells suppressed the tumoricidal activities of syngeneic $\mathrm{CD} 8^{+}$cells against HepG2 cells in a PD-1-dependent manner.

\section{Discussion}

Recently, the prognosis of patients with $\mathrm{CD} 14^{+}$cells expressing a high level of PD-L1 was found to be poor in patients with ovarian or cervical cancers ${ }^{23,24}$. However, few studies exist on PD-L2 expression by CD14 ${ }^{+}$cells from patients with diverse cancers. In our study, the prognosis of HCC patients with PD-L1 $1^{+} \mathrm{PD}-\mathrm{L} 2^{+} \mathrm{CD} 14^{+}$ cells was poorer than that of patients with other types of $\mathrm{CD} 14^{+}$cells. To the best of our knowledge, this is the first report showing that PD-L2 expression on $\mathrm{CD} 14^{+}$cells was associated with a poor prognosis in patients with HCC. Of these patients, we compared the prognosis of advanced-stage $\mathrm{HCC}$ patients with PD-L1 ${ }^{+} \mathrm{PD}-\mathrm{L} 2^{+} \mathrm{CD} 14^{+}$ cells to that of such patients with other types of $\mathrm{CD} 14^{+}$cells. The prognosis of advanced-stage HCC patients with $\mathrm{PD}-\mathrm{L} 1^{+} \mathrm{PD}-\mathrm{L} 2^{+} \mathrm{CD} 14^{+}$cells was poorer than that of similar patients with other types of $\mathrm{CD} 14^{+}$cells. Thus, this suggests that $\mathrm{PD}-\mathrm{L} 1^{+} \mathrm{PD}-\mathrm{L} 2^{+} \mathrm{CD} 14^{+}$cells may be a predictive marker of a poor prognosis in $\mathrm{HCC}$ patients. However, compared to other studies on the prognosis of patients with diverse cancers, this study had a relatively short follow-up period; a longer follow-up is required in future. 
(a) IL-12

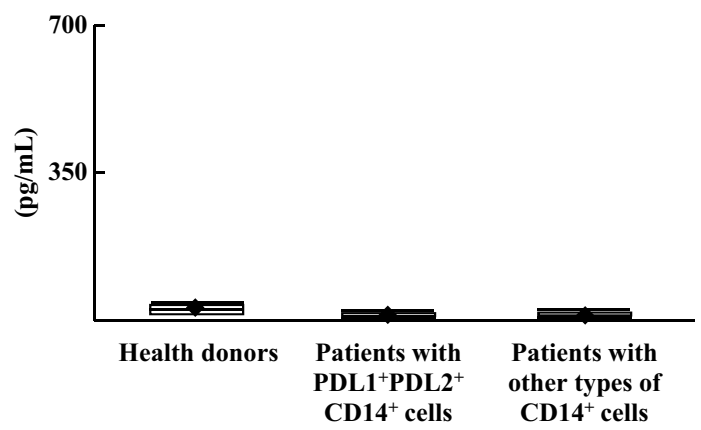

(c) $\mathrm{CCL17}$

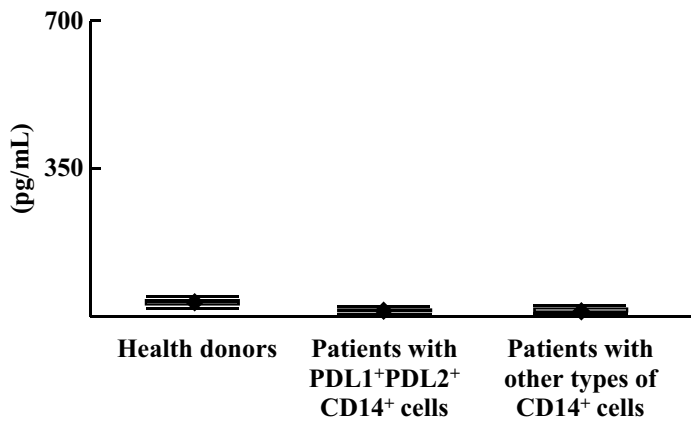

(e) CXCL13

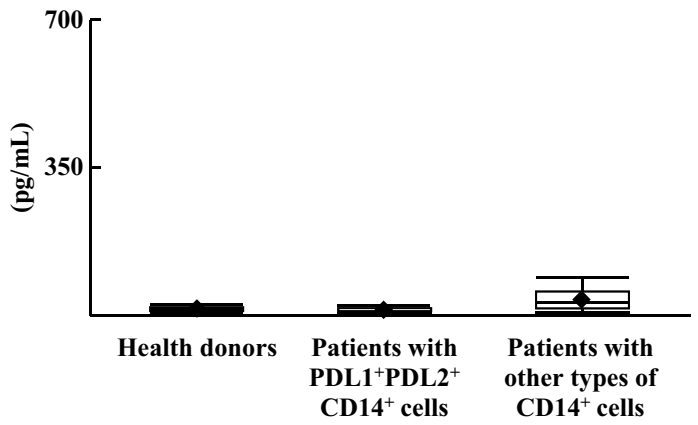

(b) IL-10

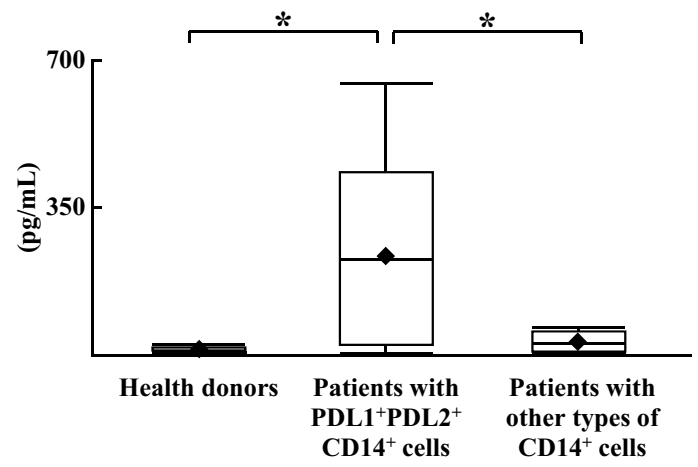

(d) CCL1

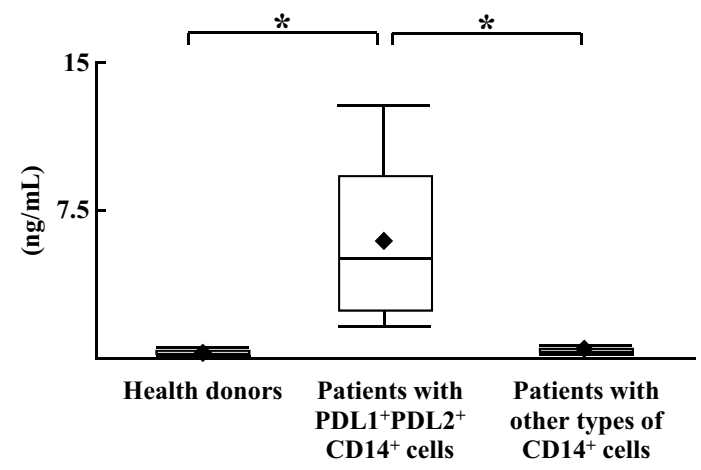

(f) Tumoricidal activity

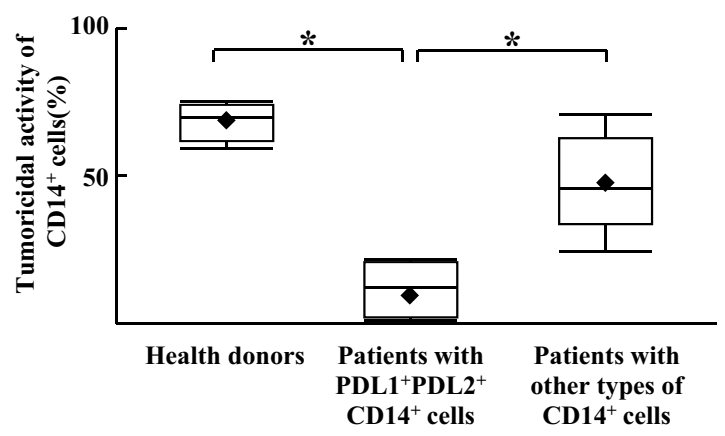

Figure 4. $\mathrm{CD} 14^{+}$cell properties of HCC patients. PD-L1 $1^{+} \mathrm{PD}-\mathrm{L} 2^{+} \mathrm{CD} 14^{+}$cells or other types of $\mathrm{CD} 14^{+}$cells were cultured for $24 \mathrm{~h}$. Culture fluids obtained were assayed for (a) IL-12, (b) IL-10, (c) CCL17, (d) CCL1, and (e) CXCL13 by ELISA. (f) The tumoricidal activities of CD14 ${ }^{+}$cells against HepG2 cells were calculated by a lactate dehydrogenase $(\mathrm{LDH})$ release assay. ${ }^{\star} p<0.05$.

Classically activated $\mathrm{M} \varphi(\mathrm{M} 1 \mathrm{M} \varphi)$, which are IL-12-producing and IL-10-non-producing $\mathrm{M} \varphi$, are major effector cells in innate immune responses ${ }^{25,26}$. In contrast, alternatively activated $\mathrm{M} \varphi(\mathrm{M} 2 \mathrm{M} \varphi)$ produce IL-10 but not IL-12 and have a reduced capacity to kill tumor cells ${ }^{27,28}$. These latter cells suppressed the tumoricidal activities of other type 1 tumor-killing cells (M1M $\varphi$, CTLs, NK cells and DCs) ${ }^{29}$. Three different subtypes of M2M $\varphi$ $(\mathrm{M} 2 \mathrm{aM} \varphi, \mathrm{M} 2 \mathrm{bM} \varphi$ and $\mathrm{M} 2 \mathrm{cM} \varphi$ ) have been described and can be distinguished from each other by chemokine profile ${ }^{30,31} \cdot \operatorname{M} 2 \mathrm{bM} \varphi$ produce IL-10 and CCL1 and are thought to predominate in patients with advanced-stage $\mathrm{HCC}^{7}$. In this study, PD-L1 ${ }^{+} \mathrm{PD}-\mathrm{L} 2{ }^{+} \mathrm{CD} 14^{+}$cells produced IL-10 and CCL1, but did not have tumoricidal activities. Therefore, these cells expressed an M2b-like phenotype; the PD-1 pathway may be one of mechanisms by which $\mathrm{M} 2 \mathrm{bM} \varphi$ suppresses tumoricidal activities of other type 1 tumor-killing cells.

$\mathrm{PD}-\mathrm{L} 1^{+} \mathrm{PD}-\mathrm{L} 2^{+} \mathrm{CD} 14^{+}$cells suppressed the tumoricidal activities of $\mathrm{CD}^{+}$cells from the same individual; anti-PD-1 antibody restored tumoricidal activities. However, paradoxically, PD-L1 negative tumors have been observed to sometimes respond to anti-PD-1 antibody ${ }^{17,18}$. Three primary reasons may exist for why this has been observed: The first may be the presence of a false negative caused by technical issues (e.g., inadequate sampling of the tumor, or insufficient sensitivity of the detection technique that is used). A second reason may be immune cell inhibition through PD-L2. A third reason may be the existence of a potential role for the PD-1 
(a)

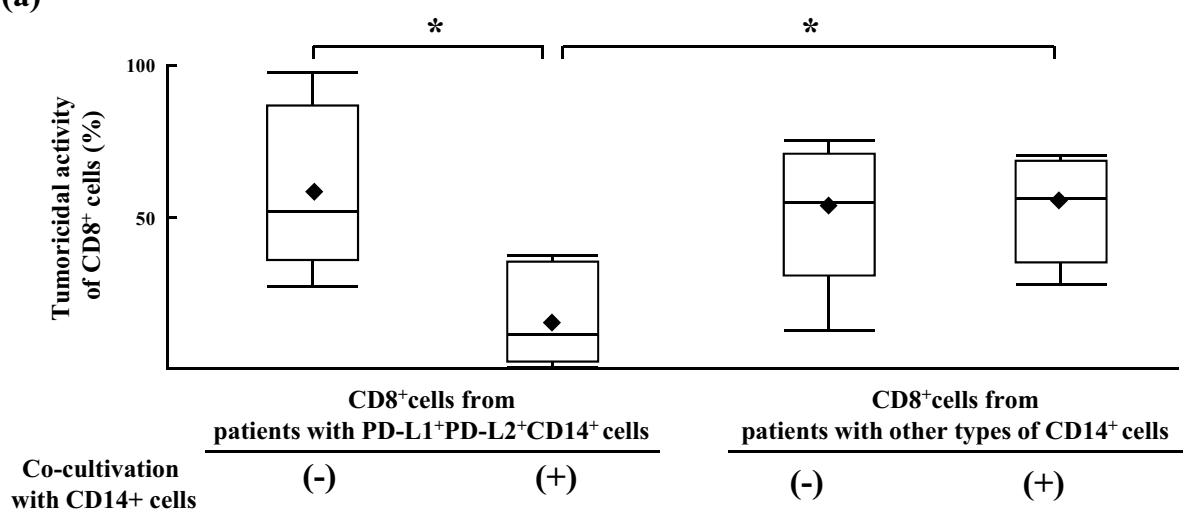

(b)

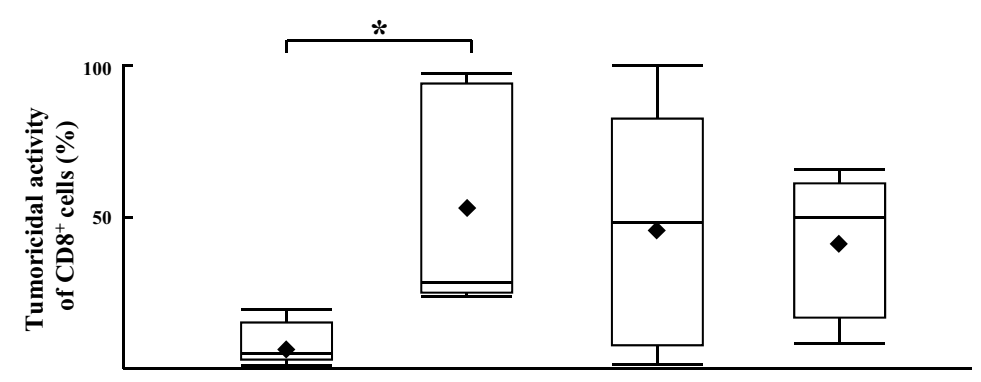

$\begin{array}{rrrrr}\text { CD14 }^{+} \text {cells } & (+) & (+) & (-) & (-) \\ \text { Anti-PD-1 Ab } & (-) & (+) & (-) & (+)\end{array}$

Figure 5. Anti-PD-1 antibody restored tumoricidal activities of $\mathrm{CD} 8^{+}$cells suppressed by $\mathrm{PD}-\mathrm{L} 1^{+} \mathrm{PD}-$ $\mathrm{L} 2^{+} \mathrm{CD} 14^{+}$cells from the same patient. (a) $\mathrm{CD} 8^{+}$cells and $\mathrm{CD} 14^{+}$cells were isolated from the same patients with PD-L1 ${ }^{+} \mathrm{PD}-\mathrm{L} 2^{+} \mathrm{CD} 14^{+}$cells $(\mathrm{n}=5)$. $\mathrm{CD}^{+}$cells $\left(5 \times 10^{5}\right.$ cells $\left./ \mathrm{ml}\right)$ and $\mathrm{CD} 14^{+}$cells $\left(5 \times 10^{5} \mathrm{cells} / \mathrm{ml}\right)$ were separately stimulated by HepG 2 homogenates (corresponding to $2 \times 10^{5}$ cells $/ \mathrm{ml}$ ) for $24 \mathrm{~h}$. After washing, $\mathrm{CD} 8^{+}$cells were co-cultured with $\mathrm{CD} 14^{+}$cells or without. $24 \mathrm{~h}$ after co-cultivation, $\mathrm{CD} 8^{+}$cells were isolated and the tumoricidal activities of these $\mathrm{CD} 8^{+}$cells against HepG2 cells were measured by LDH release assay. And, tumoricidal activity of $\mathrm{CD} 8^{+}$cells from patients with other types of $\mathrm{CD} 14^{+}$cells $(\mathrm{n}=5)$ were measured by the same methods. (b) $\mathrm{CD} 8^{+}$cells $(\mathrm{n}=5)$ and $\mathrm{CD} 14^{+}$cells from the same patients were separately stimulated by HepG2 homogenates for $24 \mathrm{~h}$. After washing, $\mathrm{CD} 8^{+}$cells that were co-cultured with $\mathrm{CD} 14^{+}$cells under the stimulation of anti-PD-1 antibody $(50 \mu \mathrm{g} / \mathrm{ml})$ or without for $24 \mathrm{~h}$. After washing CD8 ${ }^{+}$cells again, the tumoricidal activities of these $\mathrm{CD} 8^{+}$cells against HepG2 cells calculated by the LDH release assay. ${ }^{*} p<0.05$ (Mann-Whitney $U$ test).

pathway outside of the tumor microenvironment ${ }^{19,32,33}$. In the present study, we found a mechanism whereby coincubation of $\mathrm{CD}^{+}$cells with $\mathrm{PD}-\mathrm{L} 1^{+} \mathrm{PD}-\mathrm{L} 2^{+} \mathrm{CD} 14^{+}$cells led to the inhibition of tumoricidal activities by the latter; an anti-PD-1 antibody restored tumoricidal activities. The inhibition of tumoricidal activities may be associated with the binding of $\mathrm{PD}-\mathrm{L} 1$ or $\mathrm{PD}-\mathrm{L} 2$ on $\mathrm{CD} 14^{+}$cells to $\mathrm{PD}-1$ on $\mathrm{CD} 8^{+}$cells, while the restorative effect of anti-PD-1 antibody may be associated with competitive binding of the antibody with PD-L1 or PD-L2 on $\mathrm{CD} 14^{+}$cells. This suggests a mechanism by which PD-L1-negative tumors may show an apparent response to anti-PD-1 antibody. However, in vitro results only form the basis of this study. Further studies are required to measure PD-L1 and PD-L2 expression on $\mathrm{CD} 14^{+}$cells in patients with HCC prior to treatment with anti-PD-1 antibody and to confirm the effectiveness of anti-PD-1 antibody on such patients.

In our study, we used tumoricidal activity against HepG2 cell line. This cell line is derived from hepatoblastoma and not from hepatocellular carcinoma. There are many liver cancer lines and Huh7 cell line is one of the most famous cell lines from hepatocellular carcinoma. It is reported that there was a different response against chemotherapy and hypoxia between HepG2 cell line and Huh7 cell line ${ }^{34}$. However, PD-L1 expressions of cancer cell lines were not different in HepG2 cell line and Huh7 cell line ${ }^{35}$. Therefore, there may be no difference between those cell lines regarding the immune response through PD-1 pathway targeted in this study. The further experiments are needed in this point.

In summary, $\mathrm{PD}-\mathrm{L} 1^{+} \mathrm{PD}-\mathrm{L} 2^{+} \mathrm{CD} 14^{+}$cells may suppress the antitumor response of some patients with HCC. Such inhibitory functions of $\mathrm{CD} 14^{+}$cells may be associated with a poor prognosis in such patients. However, studies on bigger patient cohorts are required to draw more definitive conclusions. 


\section{Materials and methods}

Ethics statement. The study was approved by the Institutional Review Board of the Osaka Medical College (IRB approved number: 2127). Written informed consent for this research was obtained from all patients. All experiments were conducted in accordance with the relevant guidelines and regulations of Osaka Medical College.

Patients and specimens. One hundred and one patients with HCC who were hospitalized at Osaka Medical College Hospital from October 2017 to June 2019 were enrolled in this study. In this study, all patients have never been treated or have received only one treatment. Patients were classified into either an early-stage group, which consisted of patients diagnosed as very early-stage or early-stage HCC according to the Barcelona Clinic Liver Cancer (BCLC) staging system, or an advanced-stage group, which consisted of patients diagnosed as intermediate-stage or advanced-stage HCC. The following 14 patients were excluded: patients with primary or secondary immunodeficiencies (e.g., other cancers, autoimmune diseases, hematologic diseases, infections, chronic heart failure, chronic renal failure, multiple organ failure); and those who were receiving multikinase inhibitors or immunosuppressive agents (Fig. 1).

Materials. Anti-CD14 magnetic particles-DM, anti-CD8 magnetic particles-DM and IMag buffer were purchased from BD Biosciences (San Jose, CA, USA). Phycoerythrin (PE)-conjugated anti-human PD-L1 monoclonal antibody (mAb), allophycocyanin (APC)-conjugated anti-human PD-L2 mAb, interleukin(IL)-12 ELISA MAX kits and IL-10 ELISA MAX kits were purchased from BioLegend (San Diego, CA, USA). Human recombinant $\mathrm{C}-\mathrm{C}$ motif chemokine ligand 1 (rCCL1), rCCL17, and recombinant $\mathrm{C}-\mathrm{X}-\mathrm{C}$ motif chemokine 13 (rCXCL13) were purchased from PeproTech (Rocky Hill, NJ, USA). Anti-CCL17 mAbs, anti-CCL1 mAbs, and anti-CXCL13 mAbs were purchased from R\&D Systems (Minneapolis, MN, USA). Cytotoxicity detection kits (lactate dehydrogenase $[\mathrm{LDH}]$ release assay) were purchased from Roche Diagnostics (Mannheim, Germany). We performed all experiments using these kits according to the protocol of the manufacturer. Anti-PD-1 (pembrolizumab) humanized antibody was purchased from BioVision (Milpitas, CA, USA). HepG2 cells (human hepatocellular carcinoma cells), purchased from DS Pharma Biomedical (Osaka, Japan), were cultured at $37^{\circ} \mathrm{C}$ in HepG2 human hepatocellular carcinoma expansion medium (Cellular Engineering Technologies Inc., Coralville, IA, USA). RPMI-1640 medium supplemented with $10 \%$ fetal bovine serum was used for CD $14^{+}$and CD8 ${ }^{+}$ cells.

Isolation of $\mathrm{CD}_{14}{ }^{+}$and CD8 ${ }^{+}$cells. Blood samples were obtained the time of admission for the operation. Ten $\mathrm{ml}$ whole blood was drawn into a vacutainer tube containing a small amount of sodium heparin at the same time as a patient examination was conducted at admission. Peripheral blood mononuclear cells (PBMC) were isolated from heparinized whole blood by Lymphocyte Separation Medium 1,077 density gradient centrifugation. PBMC $\left(5 \times 10^{6}\right.$ cells $\left./ \mathrm{ml}\right)$ in IMag buffer were incubated with magnetic beads coated with anti-CD14 mAb $\left(40 \mathrm{~min}\right.$ at $\left.4{ }^{\circ} \mathrm{C}\right)$ and $\mathrm{CD} 14^{+}$cells subsequently magnetically harvested. When these CD14 ${ }^{+}$cells were stained for $\mathrm{CD} 16$ and $\mathrm{CD} 68$, most of these cells were $\mathrm{CD} 14^{+} \mathrm{CD} 16^{-} \mathrm{CD} 68^{-}$cells (SI Fig. S5). $\mathrm{CD}^{+}$cells were magnetically harvested using a similar method.

$\mathrm{CD} 14^{+}$cell characterization. $\mathrm{CD} 14^{+}$cells in FACS buffer were incubated with PE-conjugated anti-human PD-L1, APC-conjugated anti-human PD-L2, or isotype control $\mathrm{mAb}$ for $15 \mathrm{~min}$ at $4{ }^{\circ} \mathrm{C}$. After washing, PD-L1 and PD-L2 expression of $\mathrm{CD} 14^{+}$cells were measured by FACSAria flow cytometer and analyzed by FlowJo software ver. 10.6.0. In some experiments, $\mathrm{CD} 14^{+}$cells $\left(1 \times 10^{6}\right.$ cells $\left./ \mathrm{ml}\right)$ were cultured for $24 \mathrm{~h}$. Culture fluids obtained were assayed for IL-12 (M1M $\varphi$ biomarker), IL-10 (M2M $\varphi$ biomarker), CCL17 (M2aM $\varphi$ biomarker), CCL1 (M2bM $\varphi$ biomarker) and CXCL13 (M2cM $\varphi$ biomarker) by ELISA.

Next, CD $14^{+}$cells $\left(5 \times 10^{5}\right.$ cells $\left./ \mathrm{ml}\right)$ were stimulated by HepG2 homogenates for $24 \mathrm{~h}$. HepG2 homogenates were made by crushing HepG2 cells $\left(2 \times 10^{6}\right.$ cells $\left./ \mathrm{ml}\right)$ in PBS using an ultrasonic crusher for $15 \mathrm{~min}$. After washing, CD14 ${ }^{+}$cells were co-cultured with HepG2 cells $\left(1 \times 10^{5}\right.$ cells $\left./ \mathrm{ml}\right)$ for $24 \mathrm{~h}$. The tumoricidal activities of $\mathrm{CD} 14^{+}$cells against HepG 2 cells were calculated by LDH release assay.

Co-cultivation and tumoricidal activities of $\mathrm{CD}^{+}$cells. $\mathrm{CD}^{+}$cells $\left(5 \times 10^{5}\right.$ cells $\left./ \mathrm{ml}\right)$ and CD $14^{+}$cells $\left(5 \times 10^{5}\right.$ cells $\left./ \mathrm{ml}\right)$ from the same patients were separately stimulated by HepG2 homogenates (corresponding to $2 \times 10^{5}$ cells $/ \mathrm{ml}$ ) for $24 \mathrm{~h}$. After washing, $\mathrm{CD}^{+}$cells co-cultured with CD14 ${ }^{+}$cells under no stimulation for $24 \mathrm{~h}$. After washing again, CD8 ${ }^{+}$cells obtained $\left(5 \times 10^{5}\right.$ cells $\left./ \mathrm{ml}\right)$ and HepG2 cells $\left(1 \times 10^{5}\right.$ cells $\left./ \mathrm{ml}\right)$ were mixed in the U-bottomed wells of a 96-well microplate for $24 \mathrm{~h}$ and the tumoricidal activities of CD8 ${ }^{+}$cells against HepG2 cells calculated by the LDH release assay. Tumoricidal activity of $\mathrm{CD}^{+}$cells against Huh7 cells were assayed for same methods. For the experiments for anti-PD- 1 antibody, CD $8^{+}$cells $\left(5 \times 10^{5}\right.$ cells $\left./ \mathrm{ml}\right)$ and CD14 ${ }^{+}$cells $\left(5 \times 10^{5}\right.$ cells $/ \mathrm{ml}$ ) were separately stimulated by HepG2 homogenates (corresponding to $2 \times 10^{5} \mathrm{cells} / \mathrm{ml}$ ) for $24 \mathrm{~h}$. After washing, $\mathrm{CD}^{+}$cells that were co-cultured with $\mathrm{CD} 14^{+}$cells $\left(5 \times 10^{5}\right.$ cells $\left./ \mathrm{ml}\right)$ under the stimulation of anti-PD-1 antibody $(50 \mu \mathrm{g} / \mathrm{ml})$ for $24 \mathrm{~h}$. After washing again, $\mathrm{CD}^{+}$cells of each group were obtained. These CD8 ${ }^{+}$cells $\left(5 \times 10^{5}\right.$ cells $\left./ \mathrm{ml}\right)$ and HepG2 cells $\left(1 \times 10^{5}\right.$ cells $\left./ \mathrm{ml}\right)$ were mixed in the U-bottomed wells of a 96-well microplate for $24 \mathrm{~h}$ and the tumoricidal activities of $\mathrm{CD}^{+}$cells against HepG2 cells calculated by the LDH release assay.

Statistical analyses. Statistical analyses were performed using JMP Pro software ver. 14 (Tokyo, Japan).

Quantitative values are expressed as means. Differences in quantitative values between two groups were analyzed using a Mann-Whitney $U$ test. Differences in ratios between two groups were analyzed using Fisher's 
exact test. For survival analysis, the Kaplan-Meier method was used to analyze overall survival and a log-rank test was used for comparisons. With box charts, the horizontal lines denoted median values and closed diamonds denoted the mean values. Results were considered significant if the $p$ value was $<0.05$.

Received: 27 January 2020; Accepted: 8 June 2020

Published online: 25 June 2020

\section{References}

1. Villanueva, A. Hepatocellular carcinoma. N. Engl. J. Med. 380, 1450-1462. https://doi.org/10.1056/NEJMra1713263 (2019).

2. Poon, R. T. et al. Improving survival results after resection of hepatocellular carcinoma: A prospective study of 377 patients over 10 years. Ann. Surg. 234, 63-70. https://doi.org/10.1097/00000658-200107000-00010 (2001).

3. Dhir, M. et al. A review and update of treatment options and controversies in the management of hepatocellular carcinoma. Ann. Surg. 263, 1112-1125. https://doi.org/10.1097/sla.0000000000001556 (2016).

4. Cabibbo, G. et al. Survival of patients with hepatocellular carcinoma (HCC) treated by percutaneous radio-frequency ablation (RFA) is affected by complete radiological response. PLoS One 8, e70016. https://doi.org/10.1371/journal.pone.0070016 (2013).

5. Morimoto, O. et al. Diagnosis of intrahepatic metastasis and multicentric carcinogenesis by microsatellite loss of heterozygosity in patients with multiple and recurrent hepatocellular carcinomas. J. Hepatol. 39, 215-221. https://doi.org/10.1016/s0168 -8278(03)00233-2 (2003).

6. Feo, F. \& Pascale, R. M. Multifocal hepatocellular carcinoma: Intrahepatic metastasis or multicentric carcinogenesis?. Ann. Transl. Med. 3, 4. https://doi.org/10.3978/j.issn.2305-5839.2014.12.08 (2015).

7. Asai, A. et al. Host antitumor resistance improved by the macrophage polarization in a chimera model of patients with HCC. Oncoimmunology 6, e1299301. https://doi.org/10.1080/2162402x.2017.1299301 (2017).

8. Mittal, D., Gubin, M. M., Schreiber, R. D. \& Smyth, M. J. New insights into cancer immunoediting and its three component phases-elimination, equilibrium and escape. Curr. Opin. Immunol. 27, 16-25. https://doi.org/10.1016/j.coi.2014.01.004 (2014).

9. Im, S. J. et al. Defining CD8 ${ }^{+} \mathrm{T}$ cells that provide the proliferative burst after PD-1 therapy. Nature 537, 417-421. https://doi. org/10.1038/nature19330 (2016).

10. Chikuma, S. et al. PD-1-mediated suppression of IL-2 production induces CD8+ T cell anergy in vivo. J. Immunol. 182, 6682-6689. https://doi.org/10.4049/jimmunol.0900080 (2009).

11. Iwai, Y. et al. Involvement of PD-L1 on tumor cells in the escape from host immune system and tumor immunotherapy by PD-L1 blockade. Proc. Natl. Acad. Sci. USA 99, 12293-12297. https://doi.org/10.1073/pnas.192461099 (2002).

12. Yang, H., Zhou, X., Sun, L. \& Mao, Y. Correlation between PD-L2 expression and clinical outcome in solid cancer patients: A meta-analysis. Front. Oncol. 9, 47. https://doi.org/10.3389/fonc.2019.00047 (2019).

13. Cha, J. H., Chan, L. C., Li, C. W., Hsu, J. L. \& Hung, M. C. Mechanisms controlling PD-L1 expression in cancer. Mol. Cell 76, 359-370. https://doi.org/10.1016/j.molcel.2019.09.030 (2019).

14. Sideras, K. et al. PD-L1, galectin-9 and CD8(+) tumor-infiltrating lymphocytes are associated with survival in hepatocellular carcinoma. Oncoimmunology 6, e1273309. https://doi.org/10.1080/2162402x.2016.1273309 (2017).

15. Ma, L. J. et al. Clinical significance of PD-1/PD-Ls gene amplification and overexpression in patients with hepatocellular carcinoma. Theranostics 8, 5690-5702. https://doi.org/10.7150/thno.28742 (2018).

16. Gao, Q. et al. Overexpression of PD-L1 significantly associates with tumor aggressiveness and postoperative recurrence in human hepatocellular carcinoma. Clin. Cancer Res. 15, 971-979. https://doi.org/10.1158/1078-0432.Ccr-08-1608 (2009).

17. El-Khoueiry, A. B. et al. Nivolumab in patients with advanced hepatocellular carcinoma (CheckMate 040): An open-label, noncomparative, phase $1 / 2$ dose escalation and expansion trial. Lancet 389, 2492-2502. https://doi.org/10.1016/s0140-6736(17)31046 $-2(2017)$.

18. Kang, Y. K. et al. Nivolumab in patients with advanced gastric or gastro-oesophageal junction cancer refractory to, or intolerant of, at least two previous chemotherapy regimens (ONO-4538-12, ATTRACTION-2): A randomised, double-blind, placebo-controlled, phase 3 trial. Lancet 390, 2461-2471. https://doi.org/10.1016/s0140-6736(17)31827-5 (2017).

19. Sun, C., Mezzadra, R. \& Schumacher, T. N. Regulation and function of the PD-L1 checkpoint. Immunity 48, 434-452. https://doi. org/10.1016/j.immuni.2018.03.014 (2018).

20. Shen, X. \& Zhao, B. Efficacy of PD-1 or PD-L1 inhibitors and PD-L1 expression status in cancer: Meta-analysis. BMJ 362, k3529. https://doi.org/10.1136/bmj.k3529 (2018).

21. Alsaab, H. O. et al. PD-1 and PD-L1 checkpoint signaling inhibition for cancer immunotherapy: Mechanism, combinations, and clinical outcome. Front. Pharmacol. 8, 561. https://doi.org/10.3389/fphar.2017.00561 (2017).

22. Dong, H. et al. Tumor-associated B7-H1 promotes T-cell apoptosis: A potential mechanism of immune evasion. Nat. Med. 8, 793-800. https://doi.org/10.1038/nm730 (2002).

23. Maine, C. J. et al. Programmed death ligand-1 over-expression correlates with malignancy and contributes to immune regulation in ovarian cancer. Cancer Immunol. Immunother. 63, 215-224. https://doi.org/10.1007/s00262-013-1503-x (2014).

24. Zhang, Y., Zhu, W., Zhang, X., Qu, Q. \& Zhang, L. Expression and clinical significance of programmed death-1 on lymphocytes and programmed death ligand-1 on monocytes in the peripheral blood of patients with cervical cancer. Oncol. Lett. 14, 7225-7231. https://doi.org/10.3892/ol.2017.7105 (2017).

25. Gordon, S. Alternative activation of macrophages. Nat. Rev. Immunol. 3, 23-35. https://doi.org/10.1038/nri978 (2003).

26. Mosser, D. M. The many faces of macrophage activation. J. Leukoc. Biol. 73, 209-212. https://doi.org/10.1189/jlb.0602325 (2003).

27. Mantovani, A. et al. The chemokine system in diverse forms of macrophage activation and polarization. Trends Immunol. 25, 677-686. https://doi.org/10.1016/j.it.2004.09.015 (2004).

28. Katakura, T., Miyazaki, M., Kobayashi, M., Herndon, D. N. \& Suzuki, F. CCL17 and IL-10 as effectors that enable alternatively activated macrophages to inhibit the generation of classically activated macrophages. J. Immunol. 172, 1407-1413. https://doi. org/10.4049/jimmunol.172.3.1407 (2004).

29. Kobayashi, M. et al. M2b monocytes predominated in peripheral blood of severely burned patients. J. Immunol. 185, 7174-7179. https://doi.org/10.4049/jimmunol.0903935 (2010).

30. Sironi, M. et al. Differential regulation of chemokine production by Fcgamma receptor engagement in human monocytes: Association of CCL1 with a distinct form of M2 monocyte activation (M2b, Type 2). J. Leukoc. Biol. 80, 342-349. https://doi.org/10.1189/ jlb.1005586 (2006)

31. Edwards, J. P., Zhang, X., Frauwirth, K. A. \& Mosser, D. M. Biochemical and functional characterization of three activated macrophage populations. J. Leukoc. Biol. 80, 1298-1307. https://doi.org/10.1189/jlb.0406249 (2006).

32. Jenkins, R. W., Barbie, D. A. \& Flaherty, K. T. Mechanisms of resistance to immune checkpoint inhibitors. Br. J. Cancer 118, 9-16. https://doi.org/10.1038/bjc.2017.434 (2018).

33. Carbognin, L. et al. Differential activity of Nivolumab, Pembrolizumab and MPDL3280A according to the tumor expression of programmed death-Ligand-1 (PD-L1): Sensitivity analysis of trials in melanoma, lung and genitourinary cancers. PLoS One 10, e0130142. https://doi.org/10.1371/journal.pone.0130142 (2015). 
34. Dubbelboer, I. R., Pavlovic, N., Heindryckx, F., Sjogren, E. \& Lennernas, H. Liver cancer cell lines treated with doxorubicin under normoxia and hypoxia: Cell viability and oncologic protein profile. Cancers (Basel) https://doi.org/10.3390/cancers11071024 (2019).

35. Huang, F. et al. MicroRNA-374b inhibits liver cancer progression via down regulating programmed cell death-1 expression on cytokine-induced killer cells. Oncol. Lett. 15, 4797-4804. https://doi.org/10.3892/ol.2018.7951 (2018).

Acknowledgements

This research was supported by Japan Society for the Promotion of Science, Grants-in-Aid for Scientific Research (C) number $18 \mathrm{~K} 08018$.

\section{Author contributions}

Conception and design of the study: H.Y. and A.A. Acquisition of data: H.Y., A.A., H.O. and Y.T. Statistical analysis: H.Y. and A.A. Interpretation of data and drafting manuscript: H.Y. and A.A. Critical revision and study supervision: A.A., S.F. and K.H.

\section{Competing interests}

The authors declare no competing interests.

\section{Additional information}

Supplementary information is available for this paper at https://doi.org/10.1038/s41598-020-67497-2.

Correspondence and requests for materials should be addressed to A.A.

Reprints and permissions information is available at www.nature.com/reprints.

Publisher's note Springer Nature remains neutral with regard to jurisdictional claims in published maps and institutional affiliations.

(c) (i) Open Access This article is licensed under a Creative Commons Attribution 4.0 International License, which permits use, sharing, adaptation, distribution and reproduction in any medium or format, as long as you give appropriate credit to the original author(s) and the source, provide a link to the Creative Commons license, and indicate if changes were made. The images or other third party material in this article are included in the article's Creative Commons license, unless indicated otherwise in a credit line to the material. If material is not included in the article's Creative Commons license and your intended use is not permitted by statutory regulation or exceeds the permitted use, you will need to obtain permission directly from the copyright holder. To view a copy of this license, visit http://creativecommons.org/licenses/by/4.0/.

(c) The Author(s) 2020 